Report, for the benefit of authors as regards new textbooks, and for his own benefit, as regards reprinting existing books. Examining bodies could help by expressing, with increasing firmness, their preference for the new conventions. But the real demand for willing help must fall on the teacher, and we hope that all concerned with the teaching of elementary optics will be willing to welcome the change when the opportunity for it reaches them, and even, if they feel they can, to initiate it themselves meanwhile. All such teachers should examine this Report. At first glance it seems to sweep with dismaying rapidity through a mathematical optics that is quite beyond a school syllabus, but on careful reading it shows its authority and its value even for the most elemen. tary teaching. The appendixes should be read together, and not taken as restricted each to its own convention. Each develops methods and proofs applicable with any convention. The examples seem rather ill-chosen for illustrating the use of signs in elementary work, but on closer examination do reveal the working of the rules, and as solved independently by two experts they are really entertaining.

The Committee does not wish to restrict the liberty of the teacher as regards methods of approach and treatment of the subject. The only restrictions it wishes to impose are concerned with routine matters such as conventions of sign. There has been ample opportunity for discussion of rival conventions, and now that a pronouncement has been made it is to be hoped that in the course of time all will comply with these recommendations. Not to do so would seem to be to deny the readiness of scientific workers to accept a simplification of unnecessarily complicated affairs.

\title{
Obituary
}

\section{Dr. Michael Grabham}

$\mathrm{I}^{\mathrm{N}}$ $\mathrm{N}$ the death on January 28 of Dr. Michael Grabham at the great age of ninety-five years, the island of Madeira has lost its most influential personality and the world an enthusiastic naturalist. Dr. Grabham, who was educated at King's College, London, and the University of London, qualified in 1861 at St. Thomas's Hospital and served there as house surgeon. He married Mary Blandy, one of the well-known family of merchant shippers, in 1865 , and took up permanent residence as a practitioner on the island of Madeira. In that favoured island he produced a book dealing with its every aspectnatural and sociological-a treatise that is still of outstanding value despite the changing times.

Dr. Grabham usually paid a flying visit to his home country every summer, where he was recognised by many distinguished bodies. He received the degrees of M.D. and LL.D. from the University of Aberdeen ; F.R.C.P. from the Royal College of Physicians, which he represented at the Geological Society's centenary meeting in 1907. In 1921 he delivered the Bradshaw lecture before the College. He delivered discourses at the Royal Institution and read papers on the climate and natural history of Madeira before the British Association, of which a few years ago he became the senior member. His last paper before the latter body was read in his eighty-eighth year and dealt with the subtropical deep sea food fishes of Madeira.

The Zoological Society of London some years ago established a collecting station in Madeira and to-day can show an unrivalled series of 'Madeira tanks' in its aquarium, each displaying some aspect of the wonderful fauna which exists in the island's coastal waters. For this exhibition Dr. Grabham is partly responsible, since he was first to suggest making Madeira a base of operations. Dr. Grabham, although not a professional marine biologist himself, was an enthusiastic aider and abettor of all who made marine biology their peculiar interest.

Among Dr. Grabham's numerous activities were music and the collection of clocks. In the former art he proved himself specially gifted, and when visiting London had on more than one occasion the privilege of giving organ recitals in St. Paul's Cathedral. His collection of chiming clocks numbered more than two hundred, and the writer well remembers his sensations on first spending a night at his host's home at Quinta do Val, when the numerous timepieces solemnly announced the midnight hour for fully sixty minutes before and after Greenwich had agreed with his own watch as to the precise moment of that event.

Dr. Grabham leaves two sons and one daughter, one of the former, Mr. Walter Grabham, being the Government geologist in the Sudan; his daughter, Mrs. E. B. Carter, has her own home in Madeira at Santa Cruz, where she spends her holidays and supervises the collecting operations on behalf of the Zoological Society.

Dr. Grabham had many friends, and the loss of his charming and energetic personality will be deeply felt by a large circle of friends both in Great Britain and in his island home. E. G. Boulenger.

\section{Mr. Herbert G. Ponting}

THE death of Herbert G. Ponting on February 8, at the age of sixty-four years, removes from us perhaps the greatest of all polar photographers, a pioneer in the application of artistic photography to the purpose of a scientific expedition.

The early part of Ponting's life was spent in a diversity of occupations; and he took to photography from the unusual atmosphere of agriculture and mining in the western United States. He rapidly made a name for himself by his pictures in Japan 